\title{
Een revolutie in het mondiaal bestuur: naar een Wereldwijd Parlement van Burgemeesters ${ }^{*}$
}

\author{
Benjamin Barber
}

In deze bijdrage aan het themanummer over zijn eigen boek 'If Mayors Ruled the World: Dysfunctional Nations, Rising Cities' schetst Benjamin Barber eerst de achtergrond van zijn voorstel tot het oprichten van een Wereldwijd Parlement van Burgemeesters, namelijk het falen van de nationale staten bij het oplossen van de problemen van de 21e eeuw. De hoop voor een democratische oplossing ligt vooral in de opkomst van de steden en hun burgemeesters. Een cruciale rol hierbij zou een Wereldwijd Parlement van Burgemeesters moeten spelen. Volgens Barber zijn de kernvraagstukken waarmee zo'n burgemeestersparlement zich moet bezighouden de klimaatverandering, de immigratie, geweld en ordehandhaving en stedelijke autonomie. Het grootse praktische probleem bij dit project is de vraag hoe duizenden afgevaardigden op een reguliere basis bijeen kunnen komen. De technologie van het informatietijdperk biedt daarvoor de oplossing in de vorm van een virtueel platform. Het wereldwijde burgemeestersparlement is een unieke vorm van interstedelijke samenwerking die een nieuwe vorm van politiek gezag vestigt via een aanspraak op universele rechten: de rechten van steden en stadsbewoners.

\section{Achtergrond}

In deze onzekere tijd van Ebola, ISIS, klimaatverandering en immigratie, van het bestaan van wereldmarkten in handel, banen, financiën en goederen, kan er weinig twijfel over bestaan dat de natiestaat steeds disfunctioneler wordt. Dat leidt tot een crisis van zowel de democratie - gevangen als ze is binnen de grenzen van de natiestaat - als van de internationale samenwerking, die wordt belemmerd door een krampachtig vasthouden aan soevereiniteit, landsgrenzen en nationale rivaliteit. Te zeggen dat natiestaten disfunctioneel zijn is misschien zelfs nog te zwak uitgedrukt. Daniel Cohn-Bendit en Felix Marquandt schreven in 2013: “our national politicians" best-kept secret: that what they see as the be-all and end-all of modern governance, the nation-state, is in fact becoming... obsolete.' (New York Times, Opinion Pages, 2-9-2013; http://www.nytimes.com/2013/09/03/opinion/ the-fix-for-europe-people-power.html?_r=0).

Voor oplettende waarnemers als Jean Monnet waren de grenzen van de soevereiniteit al tegen het einde van de Tweede Wereldoorlog duidelijk zichtbaar. Reeds in 1943 voorzag Monnet - handelaar in cognac en visionair - de noodzaak van een transnationaal, naoorlogs Europa: 'There will be no peace in Europe if the states are reconstituted on the basis of national sovereignty. The countries of Europe are too small

* Vertaling: Gert-Jan van der Krogt, TVcN Tolk- en Vertaalcentrum Nederland; redactie van de tekst: Bas Denters en Rik Reussing. 
to guarantee their peoples the necessary prosperity and social development.' In de huidige wereld, waarin staten nog disfunctioneler zijn geworden en het prijzenswaardige Europese experiment in gedeelde soevereiniteit worstelt om het hoofd boven water te houden, kunnen we met stelligheid zeggen dat er op deze wereld geen vrede of welvaart of duurzame economische groei mogelijk is op een basis van nationale of zelfs supranationale soevereiniteit. En ook kunnen we stellen dat noch soevereine staten, noch de internationale organen die op de principes van nationale soevereiniteit zijn gestoeld het overleven van de mensheid kunnen garanderen. De nationale staat is veel te groot voor participatie door de burger, maar te klein om de wereldwijde processen die de planeet vormgeven te kunnen aanpakken.

Gegeven die overweldigende problemen is het, zoals ik reeds heb bepleit in 'If Mayors Ruled the World: Dysfunctional Nations, Rising Cities', tijd om de focus te veranderen: van staten naar steden; van presidenten en premiers naar burgemeesters en gemeenteraden. Van passieve onderdanen in grote, bureaucratische nationale overheden die menen dat burgerschap bestaat uit het af en tot uitbrengen van een stem bij verkiezingen en permanent tv kijken, tot maatschappelijk betrokken, sterke democratische burgers in gemeenten waar 'politiek' participatie en burgerbetrokkenheid impliceert.

De nieuwe 'glocal' hoop is gevestigd op steden en hun burgemeesters: hoop voor grensoverschrijdende democratische participatie en het aanpakken van problemen mondiale schaal ('global'), maar ook voor effectief plaatselijk bestuur ('local'). Steden hebben niet alleen hun veerkracht en pragmatisme bewezen in de lokale aanpak van mondiale problemen, maar werken ook samen in een indrukwekkend scala aan interstedelijke samenwerkingsverbanden, op zoek naar gemeenschappelijke oplossingen. Ze delen wereldwijd '“best practices', van stadsvisa tot burgerbegrotingen, van slim energiegebruik tot beperking van de $\mathrm{CO} 2$-uitstoot. Maar hoewel er veel interstedelijke samenwerkingsverbanden met een productieve agenda bestaan, zoals de UCLG (United Cities and Local Governments), of de ICLEI (Local Governments for Sustainability), of CityNet (het Aziatische interstedelijke samenwerkingsverband), zijn ze vaak sterk verkokerd en gericht op een beperkte problematiek, zoals de C40 Climate Cities. Ze zijn onvoldoende zichtbaar op mondiaal niveau en worden dus zelden beschouwd als een aanvulling op - laat staan als een vervanger van - de Verenigde Naties en andere internationale organisaties gebaseerd op de natiestaat, ondanks het falen van deze internationale organisaties bij het vinden van effectieve oplossingen. Wat we nodig hebben is een 'sluitstuk' op het reeds indrukwekkende scala aan interstedelijke samenwerkingsverbanden.

\section{Een Wereldwijd Parlement van Burgemeesters}

Naar mijn mening kan een Wereldwijd Parlement van Burgemeesters (WPB) een dergelijk sluitstuk vormen. Het idee van zo'n parlement poneerde ik in hoofdstuk 12 van If Mayors Ruled the World en deze gedachte is snel bijzonder populair 
geworden onder burgemeesters. Een WPB zou interstedelijke samenwerking een nieuw en krachtig gezicht op het wereldtoneel kunnen geven en een gemeenschappelijke ruimte kunnen vormen voor de vele belangrijke, reeds actieve interstedelijke organisaties. Het zou de uiteenlopende agenda's van deze samenwerkingsverbanden kunnen integreren; het zou de interstedelijke samenwerking kunnen faciliteren door gezamenlijke beslissingen van steden - die samen meer dan de helft van de wereldbevolking huisvesten in een wereld van groeiende interdependenties - democratisch te legitimeren en door uitvoeringskracht te organiseren; en het zou de wereldwijde publieke opinie vorm kunnen geven en versterken door te pleiten voor duurzaamheid, diversiteit, culturele creativiteit en sociale rechtvaardigheid: publieke goederen die niet alleen stedelijk, maar ook mondiaal van belang zijn.

Het spreekt voor zich dat een WPB niet de plaats in kan nemen van nationale en internationale politiek-bestuurlijke instituties. Het parlement zou moeten werken in de schaduw van het gezag van de soevereine staten. Evenmin zou een dergelijk parlement een plaatsvervangende, top-down 'wereldregering' van steden moeten willen zijn. Door de stedelijke bevolking en de burgemeesters als hun politieke vertegenwoordigers (die niet alleen het merendeel van de wereldbevolking vormen maar ook tachtig procent van de bevolking van de ontwikkelde wereld) samen te brengen en door zich te richten op gedeelde 'best practices' en gemeenschappelijke ambities, kan een dergelijk parlement echter wel de democratische stem van steden over de hele wereld versterken en tegelijkertijd efficiënt bestuur en productieve onderlinge afhankelijkheid binnen steden stimuleren.

Een WPB vergroot de democratische zichtbaarheid van de steden in de wereld. Steden die door hun creativiteit, diversiteit, innovatiekracht, mobiliteit, kansenrijkdom en ondernemerschap hoop bieden aan al die mensen die cynisch zijn geworden over de overheid. Het WPB komt niet in de plaats van reeds bestaande, soevereine hogere overheden waarbinnen de steden opereren en kan evenmin pretenderen iedereen te vertegenwoordigen. Niettemin kan het parlement er wel aanspraak op maken bij te dragen aan de verschaffing van publieke goederen als duurzaamheid en rechtvaardigheid en het biedt steden een gemeenschappelijk forum om hun stem te laten horen en een stedelijke publieke agenda (die gelijktijdig ook een mondiale agenda is) te formuleren.

In concrete en praktische zin kan een Wereldwijd Parlement van Burgemeesters:

- de wereldwijde publieke opinie richten op het waarderen van onderlinge afhankelijkheid, en het onderkennen van de praktische tekortkomingen van staten en op de staat gebaseerde internationale organisaties bij de oplossing van grensoverschrijdende problemen, en versterken van het besef dat steden en stedelijke netwerken kunnen bijdragen aan wereldwijde samenwerking bij het oppakken van cruciale uitdagingen als klimaatverandering, illegale immigratie, wereldmarkten van arbeid, financiën en goederen, pandemieën die een gevaar zijn voor de volksgezondheid, en internationaal terrorisme en oorlog;

- een systeem van 'mentorsteden' oprichten waarin succesvolle metropoolregio's op een grondslag van gezonde concurrentie en op solidariteit gebaseerde 
onderlinge hulp samen kunnen werken met en begeleiding kunnen geven aan opkomende metropoolregio's in ontwikkelingslanden;

- een secretariaat oprichten waarin stedelijke experts, zowel specialisten en generalisten, kunnen helpen nieuwe ideeën te ontwikkelen en bestaande ideeën ten uitvoer te brengen. Dit secretariaat kan ook toezien op de voorbereiding van de feitelijke vergaderingen van de WPB alsmede op de verkiezing van de leden van het parlement;

- borg staan voor de bescherming en bevordering van mensenrechten in steden en metropoolregio's, ook daar waar ze worden geschonden of terzijde worden geschoven door hogere overheden (zie ook de Verklaring van de Rechten van de Steden en Stadsbewoners hieronder);

- stedelijke best practices vaststellen en hun toepassing bevorderen, waarbij men onderkent dat deze praktijken aanpassing behoeven vanwege geografische, demografische, en culturele verschillen tussen steden. Voorbeelden 'best practices': verhoogde isolatienormen voor gebouwen; gebruikssensoren die energiegebruik indelen in piek- en dalperioden; het gebruiken van de gezamenlijke inkoopmacht van steden om op markten invloed uit te oefenen op particuliere bedrijven;

- het vaststellen van en waarschuwen tegen worst practices. Bijvoorbeeld: woontorens en grootschalige stedelijke 'projecten'; een stedelijk verkeers- en vervoersbeleid gericht op autogebruik; segregatie van woon- en werkwijken; het verwaarlozen of ondergeschikt maken van kunst en cultuur aan economische of commerciële belangen; het verwaarlozen van de voorwaarden voor stedelijk burgerschap en van de instituties en processen die dit burgerschap bevorderen; een naïef geloof in simplistische technologische oplossingen; en de hang om steden uit de grond te stampen in een snelle en ongeplande orgie van stedenbouw die ervoor zorgt dat de culturele, sociale en democratische ontwikkelingen geen gelijke tred kunnen houden met de fysieke groei;

- een 'netwerk der netwerken' worden, dat het sluitstuk vormt van het steeds omvangrijkere geheel van interstedelijke netwerken die reeds actief zijn. Dit netwerk der netwerken zou dan de verkokering van de bestaande netwerken, op specifieke terreinen zoals milieu, handel of veiligheid, moeten doorbreken en hun activiteiten moeten afstemmen.

- pleiten voor een integratie van de staatkundige, territoriale en fiscale jurisdictie van het stadsbestuur met de omvang van het sociaal-, economisch en cultureel verzorgingsgebied (en de bevolking van dat gebied) dat de stad daadwerkelijk bedient in één nieuwe metropoolregio die bestaat uit kernsteden, voorsteden, slaapsteden en het omliggende platteland. Deze metropoolregio's dienen ook een grotere autonomie, meer belastingmiddelen en meer beleidsbevoegdheid te hebben dan de huidige steden binnen hun verouderde stadsgrenzen. In Italië heeft de huidige premier en voormalig burgemeester van Florence, Matteo Renzi, in een recente grondwetswijziging in deze geest negen metropoolregio's ingesteld die zijn vertegenwoordigd in de Italiaanse Senaat;

- de voorwaarden scheppen voor het oprichten van een grensoverschrijdende, internationale Stadspartij die de publieke belangen van steden over de hele 
wereld zal gaan vertegenwoordigen en druk uit zal oefenen op nationale overheden om in de nationale politiek meer rekening te houden met de belangen van steden en stadsbewoners, die momenteel in grote delen van de wereld een ondervertegenwoordigde meerderheid vormen. De huidige stromingen binnen de politieke partijen - zij het conservatief of liberaal, markt-fundamentalistisch of étatistisch - vertegenwoordigen maar zelden het stedelijke gebied en de gemeenschappelijke belangen van steden in een verstedelijkte en geglobaliseerde wereld;

- interstedelijke culturele betrekkingen gebruiken om gezonde samenwerking tussen steden te ontwikkelen op terreinen waar verbeeldingskracht en creativiteit van vitaal belang zijn.

Door deze belangrijke mondiale doelen te realiseren, kan deelname van steden aan een WPB bijdragen tot een versterking van de lokale effectiviteit en productiviteit van het stedelijke bestuur. Sterker nog, dit lokale rendement van het WPB vormt de lakmoesproef voor burgemeesters, die primair het lokale belang zijn toegewijd en verantwoordelijk zijn voor het welzijn van hun eigen gemeente. Een WPB dient actief te kunnen zijn zonder dat deelname daaraan het vermogen van burgemeesters aantast om uitvoering te geven aan hun primaire taak: het besturen van de eigen gemeente. Mede daarom lijkt een WPB alleen haalbaar als het parlement slechts eens per twee jaar daadwerkelijk fysiek samenkomt en dat de overige bijeenkomsten via een virtueel platform - een soort 'Global Google Mayors Hangout' - vormkrijgen. Omwille van de haalbaarheid kan het ook nodig blijken om lokaal een 'Bureau Interstedelijke / Intergouvernementele Relaties' op te zetten, zoals dat bijvoorbeeld al bestaat in New York en Londen.

De voorbereiding van dit parlement is feitelijk al een paar jaar geleden in gang gezet (ruim voor het verschijnen van If Mayors Ruled the World). In het kader van het WPB-project zijn inmiddels drie internationale bijeenkomsten georganiseerd. De eerste bijeenkomst werd gehouden in februari 2013 in Seoul (Zuid-Korea) onder leiding van burgemeester Park Won Soon en met deelnemers afkomstig uit het CityNet-samenwerkingsverband. De tweede sessie vond plaats in New York in oktober 2013. Aan die bijeenkomst werd deelgenomen door onder meer de burgemeesters van Las Palmas (Brazilië), Santa Monica (VS), Mannheim (Duitsland), Vancouver (Canada), Perth (Australië) en Bogota (Colombia).

De derde bijeenkomst - de meest ambitieuze tot dusver - vond op 19 september 2014 plaats in Amsterdam, waar dertig steden waren vertegenwoordigd in een formele planningsbijeenkomst die werd georganiseerd onder auspiciën van de burgemeesters van de G4 (Amsterdam, Rotterdam, Utrecht en Den Haag). Aan de sessie werd deelgenomen door delegaties uit een keur aan wereldsteden, waaronder Barcelona, Wenen, Seoul, Athene, Rome, Boston, Bristol, Warschau, Los Angeles, Bratislava, New York, Mannheim, Albuquerque en een half dozijn Nederlandse steden, maar ook meer dan vijftig experts en leiders van interstedelijke samenwerkingsverbanden. Deze bijeenkomst was gericht op de inhoudelijke beleidszaken die een WPB zal moeten aanpakken en op de belangrijkste procedu- 
rele vraagstukken. Er is daarbij ook gesproken over de mogelijkheid om in de herfst van 2015 reeds een proefparlement van burgemeesters te houden in Londen.

\section{Kernvraagstukken voor een WPB}

Het WPB heeft enkel recht van bestaan als het in staat blijkt beleidsvraagstukken aan te pakken die enerzijds directe relevantie hebben voor het stedelijk bestuur en anderzijds wereldwijd belang hebben. Bovendien wordt de relevantie van het WPB groter als het in staat blijkt effectief problemen aan te pakken waar natiestaten en internationale organisaties geen oplossingen voor wisten te vinden. Er zijn feitelijk maar weinig wereldwijde vraagstukken die niet relevant zijn voor steden. Cruciale problemen waar het WPB een rol kan spelen, zijn bijvoorbeeld de klimaatverandering, immigratie, openbare orde en veiligheid en de versterking van de stedelijke autonomie. Voor elk van deze uitdagingen geldt dat een gemeenschappelijke, wereldwijde aanpak zichtbare en duurzame effecten op lokaal niveau zal hebben.

- Klimaatverandering: samenwerkende steden in netwerken als ICLEI en C40 Climate Cities hebben nu al meer resultaat geboekt dan de Verenigde Naties in de afgelopen twintig jaar. Samenwerkende steden kunnen hier - in een context waar nationaal beleid tekortschiet - veel betekenen omdat wereldwijd tachtig procent van de productie (gemeten in termen van het BNP) en een even groot percentage van de CO2-uitstoot wordt gerealiseerd in de steden. Innovatieve stedelijke projecten kunnen een sleutelrol vervullen; denk aan: autovrije zones, congestieheffingen, fietsleenprogramma's, normstelling voor de uitstoot van $\mathrm{CO} 2$ en isolatie (van bestaande en nieuwe gebouwen), de exploitatie van havens (walstroom, hybride vrachtwagens), hoogwaardig openbaar vervoer (light rail, tram en busbanen) en alternatieve energieopwekking (windturbines, geothermische energie, getijdenenergie). Een WPB opent de weg om middels gedeelde programma's, algemene normstelling en het gebruik van gezamenlijke inkoopmacht, de energiemarkt te beïnvloeden en daadwerkelijke energietransitie te bewerken.

- Immigratie: de economische migratie van 'illegalen' (mensen zonder geldige reisdocumenten) op zoek naar werk heeft - niettegenstaande pogingen van nationale staten om de immigratie te reguleren - in steden over de hele wereld geleid tot de aanwezigheid van miljoenen 'illegale' immigranten waarvan het bestaan in officiële statistieken en nationaal beleid wordt ontkend. Stadsbesturen zijn begonnen om deze bewoners van hun stad - ongeacht hun formele verblijfsstatus - middels even ingenieuze als gewaagde programma's (zoals het 'stadsidentificatiebewijs' in New York of het 'stadsvisum' in Hamburg) een positie in de stedelijke samenleving te geven. Als één of enkele steden dit soort programma's implementeren, bestaat het risico van de magneetwerking: hoe welkom migranten ter plaatse ook mogen zijn, vroeg of laat overstijgt de aantrekkingskracht van deze steden voor de immigranten het lokale vermogen om deze nieuwe stedelingen een plaats te geven. Pas wanneer steden samenwerken en allemaal dergelijke programma's invoeren 
wordt het probleem van de illegalen op stedelijk niveau hanteerbaar. En pas dan zullen de samenwerkende steden in staat zijn om een vuist te maken tegen hun nationale regering als die overweegt gerechtelijke stappen te nemen tegen deze steden en hun migranten. In feite is het zo dat, of het nu gaat om emissiegrenzen, stadsvisa of vergelijkbare programma's, die door afzonderlijke steden eigenlijk niet verantwoord kunnen worden geïmplementeerd, door samenwerkende steden - mits het merendeel van de steden zich committeert - wel degelijk kansrijk kunnen zijn.

- Openbare orde en veiligheid: wederzijds respect en rechtvaardigheid zijn essentieel voor een beschaafde samenleving. Vooral in steden waar mensen dicht op elkaar leven en waar vervreemding kan leiden tot geweld. Lokale politiekorpsen zijn belast met het handhaven van de orde en het hoeden van de wet. Maar wanneer multiculturele diversiteit en economische ongelijkheid meespelen, kan de politie soms verworden tot de bewaker van segregatie of het instrument van onverdraagzaamheid. Al te vaak vormt de politie zelf geen goede afspiegeling van de diversiteit van de gemeenschap die zij dient. Niet zelden verwordt hun legitiem geweldsmonopolie tot illegitiem en ondemocratisch gebruik van macht dat wordt misbruikt om burgers te intimideren of geweld aan te doen, in plaats van hen te beschermen. In de Verenigde Staten, waar de terreurdreiging de gevaarlijke tendens om de lokale politiemachten te militariseren heeft versterkt, lijkt de politie soms op een vreemde bezettingsmacht. Maar in Europa zien we ook dat paramilitaire eenheden als de CRS in de metropool Parijs agenten inzet die afkomstig zijn uit de periferie. Agenten die zich niet kunnen verplaatsen in de leefwereld van studenten, minderheden, noch immigranten en die onvoldoende begrijpen wat deze stedelingen drijft. Dit zijn dossiers waarbij steden elkaar kunnen helpen, vooral omdat ze zo de incidentele dreiging van terroristische aanslagen, waarbij samenwerking tussen politie-eenheden en andere paramilitaire eenheden - als die nodig mocht zijn - kan combineren met respectvolle, vriendelijke en legale omgangsvormen met de bevolking. Samen kunnen de steden de trainingsnormen en -programma's voor hun veiligheidseenheden afstemmen.

- Versterking van de stedelijke autonomie: waarschijnlijk de belangrijkste taak waar steden zich momenteel voor gesteld zien, is het zich verzekeren van de voldoende autonomie, bevoegdheden en belastinginkomsten om de stedelijke en mondiale problemen waarmee ze worden geconfronteerd het hoofd te bieden. Al te vaak wordt hun vermogen om voor de bevolking van de stedelijke regio een adequaat beleid en goede voorzieningen te realiseren belemmerd door verouderde gemeentegrenzen die geenszins aansluiten op de sociale en economische schaal van het stedelijk gebied. In de metropoolregio Detroit behoren de tien gemeenten die Detroit als centrumgemeente omgeven tot de economisch en maatschappelijk meest succesvolle van de VS. Binnen de regio vormt de centrumgemeente Detroit een failliet getto, die een grote behoefte heeft aan ruimere gemeentegrenzen, meer bevoegdheden en een grotere belastingcapaciteit. De centrumsteden krijgen van hun nationale overheid 
ook vaak 'unfunded mandates', waarbij ze worden belast met taken en verantwoordelijkheden, zonder dat ze de daarvoor benodigde financiële middelen ontvangen. In rijke landen worden steden zelfs vaak gezien als een armlastig familielid dat is aangewezen op de aalmoezen van de familie. Maar in werkelijkheid zijn steden goed voor circa tachtig procent van de nationale productie en vaak voor een nog groter aandeel in de belastingopbrengsten. Daarom kunnen ze ook aanspraak maken op een groter deel van die rijkdommen. Maar daartoe is politieke invloed nodig die alleen verkregen kan worden door samenwerking tussen steden en een gemeenschappelijke politieke strategie. Bijvoorbeeld door het oprichten van een internationale 'Stadspartij' die wereldwijd opkomt voor de stedelijke belangen. Omdat het merendeel van de wereldbevolking in stedelijke gebieden woont, moet het redelijkerwijs haalbaar zijn om langs democratische weg resultaten te boeken. Internationale samenwerking - politiek en maatschappelijk - van overheden, bedrijven en maatschappelijke organisaties is daar wel een vereiste voor.

Er zijn nog tal van domeinen - uiteenlopend van culturele samenwerking, innovatie van havengebieden en 'fair trade' tot minimumlonen - waar steden door samenwerking meer kunnen bereiken dan door onderlinge concurrentie of het kiezen van een eigen pad. Met het oog op goed bestuur, duurzaamheid en rechtvaardigheid is een WPB dan ook meer dan een optie. Zo'n Wereldwijd Parlement is hiertoe veeleer een noodzakelijke voorwaarde.

\section{Een virtueel platform voor WPB-vergaderingen}

Het grootste praktische probleem voor het WPB-project is de vraag hoe je zo'n $300-1.000$ of zelfs meer burgemeesters als vertegenwoordigers van hun metropoolregio op reguliere basis bijeen kan laten komen om informeel richting te geven aan mondiale ontwikkelingen. Zelfs de meest enthousiaste, kosmopolitische georiënteerde burgemeester zal tegenwerpen dat hij zijn handen al meer dan vol heeft aan het besturen van zijn eigen stad, en geen tijd heeft om zich ook nog eens bezig te houden met besturen van de wereld. Zelfs wanneer zij het belang van internationaal topoverleg ten volle onderschrijven, zullen maar weinig burgemeesters bereid en in staat zijn de prijs daarvan - in termen het regelmatig verblijf in het buitenland ver weg van de eigen stad en verantwoordelijkheden, de ecologische en financiële kosten en de vermoeienissen van de vereiste reizen - op te brengen. De ervaringen met de bijeenkomsten van bestaande internationale stedennetwerken, waarin - hoe graag ze ook willen - slechts zelden alle burgemeesters van deelnemende steden participeren, leert ons een harde les: als burgemeesters samen moeten regeren, dan hebben ze middelen nodig die hen in staat stellen dat vanuit 'huis' te doen. De techniek speelt daarbij een doorslaggevende rol.

In het huidige informatietijdperk is er geen enkele reden om een WPB te enten op het duizend jaar oude model van het beleggen van bijeenkomsten op één fysieke locatie. Er zijn thans alternatieven voor het klassieke model van het Congres van 
Wenen (of Westfalen!). Een WPB zal uit noodzaak zijn vergaderingen en overlegen besluitvormingstechnieken moeten baseren op moderne technologie en de innovatieve mogelijkheden van onlinebijeenkomsten en virtuele vergaderingen. In een tijdperk van Skype, Facebook, Google Hangouts, Maestro en andere opkomende softwareplatformen, die het virtueel bijeenkomen van tientallen of zelfs honderden mensen mogelijk maken, waarbij veel van de voordelen van directe persoonlijke communicatie behouden blijven, behoeven tijd, ruimte en geld niet langer meer te worden beschouwd als onoverkoombare barrières voor een Wereldwijd Parlement van Burgemeesters. Het gebruik van deze moderne netwerktechnologieën past ook goed bij het karakter van steden als wederzijds afhankelijke eenheden, die worden verbonden door interactieve stromen of het nu gaat om cultuur, handel, immigratie of transport en andere activiteiten. Nationale staten daarentegen zijn gedefinieerd in termen van hun onafhankelijkheid: ze zijn per definitie soevereine territoriale entiteiten die zijn afgegrensd van andere staten. Het is bovendien lastig voor te stellen dat wereldleiders die elkaars rivalen zijn via het internet met elkaar overleggen, maar bij vaak meer pragmatisch georiënteerde burgemeesters is een dergelijke vorm van beraad makkelijker denkbaar.

Bovendien kan een effectief 'Glocal Cyber Commons'-platform waar burgemeesters bijvoorbeeld drie keer per jaar bijeenkomen, aangevuld worden met een informatie- en uitwisselingsnetwerk (bijvoorbeeld gemodelleerd naar de City Protocol Society een internationaal publiek-privaat netwerk waarin onder meer Barcelona en CISCO participeren). Via zo'n netwerk kan tussen WPB-vergaderingen in uitwisseling en interactie plaatsvinden tussen de burgemeesters en hun plaatsvervangers, maar ook door beleidsambtenaren, experts en zelfs de burgers, die hun eigen parallelle en permanente overleg- en uitwisselingsnetwerk zouden kunnen hebben.

Hoewel de ervaring leert dat incidentele fysieke vergaderingen, bijvoorbeeld eens per twee jaar, noodzakelijk zijn - want er is overtuigend bewijs dat latere virtuele vergaderingen beduidend effectiever zijn als er in de aanloop een 'echte' ontmoeting heeft plaatsgevonden - opent het experimenteren met grootschalige virtuele bijeenkomsten waar de burgemeesters zelf (en niet hun plaatsvervangers) aan deelnemen een weg voor een praktisch en levensvatbaar Wereldwijd Parlement van Burgemeesters. Een dergelijke bijeenkomst kan met recht worden aangeduid als een 'Glokaal Parlement van Burgemeesters' omdat het tegelijkertijd lokaal (waar de afgevaardigden zich bevinden) en globaal (wereldwijd: gericht op gemeenschappelijke besluitvorming door burgemeesters op het wereldtoneel) is. In deze virtuele ontmoetingsplaats is tegelijkertijd ruimte voor 'polis' en 'kosmopolis'.

In een dergelijke entourage kan men zich voorstellen dat burgemeesters drie keer per jaar virtueel bijeenkomen en elkaar eens per twee of drie jaar werkelijk persoonlijk spreken. Door eens per vier maanden ongeveer zes uur uit te trekken - slechts 18 uur per jaar - kunnen burgemeesters regelmatig online overleggen. Goed voorbereide agenda's, vooraf doorgesproken voorstellen en initiatieven 
waarover men vooraf lokaal overleg met stakeholders heeft kunnen voeren en zorgvuldig opgestelde declaraties, zouden onderwerp van overleg en besluitvorming kunnen vormen. In zo'n parlement zijn burgemeesters goed voorbereid, worden zij niet nodeloos afgehouden van hun primair-lokale verantwoordelijkheden en worden ze niet uitgeput door nodeloos veel gereis. Aldus krijgen de hoofdrolspelers de ruimte om onderling te communiceren, overleg te voeren en tot beslissingen te komen.

Het technologisch platform waarop dergelijke bijeenkomsten plaatsvinden vormt een virtueel kosmopolitische plein dat ruimte biedt voor debat, overleg en besluitvorming. Door drie maal per jaar virtueel samen te komen zou de besluitvorming kunnen plaatsvinden in een cyclus van drie 'lezingen' per jaar, waarbij de uiteindelijke beslissing pas plaatsvindt in de derde en laatste jaarlijkse vergadering, wat voldoende tijd laat voor het verzamelen van de feiten, het polsen van meningen en tussentijds overleg.

ICT-bedrijven die sociale platforms voor persoonlijk, sociaal en consumentengebruik hebben ontworpen, hebben er niet alleen blijk van gegeven te zijn geïnteresseerd in de ontwikkeling van netwerken voor civiele en politieke participatie. Ze hebben zichzelf in de afgelopen jaren ook zelf getransformeerd in niethiërarchische ('bottom-up'), op overleg en netwerken gebaseerde organisaties. De oude hiërarchische moloch IBM ('Big Blue') heeft lang geleden al zijn organisatiemodel volledig gekanteld en is nu 'bottom-up' en milieubewust gaan werken. Aldus heeft het zijn bestaan in het moderne web-gebaseerde ICT-tijdperk verzekerd. Een ander voorbeeld van deze transformatie is CISCO Systems dat samen met de stad Barcelona een platform (City Protocol Society) heeft ingericht dat het mogelijk maakt stedelijke best practices virtueel te delen. Google heeft experimenten uitgevoerd met de inrichting van het 'Google Hangouts'-model als een kleinschalig virtueel plein waarin burgers samen kunnen komen en met elkaar en met politieke leiders (of beroemdheden) kunnen praten. Mark Zuckerberg heeft meermaals gesteld dat het principe waarop Facebook en de opvolgers daarvan gegrond zijn is dat het mensen 'dingen' samen laat doen en samen laat delen, of die 'dingen' nu commercieel, sociaal, privé (vriendschappen) of publiek ('liking') zijn. De Amerikaanse politiciloog James Fishkin heeft bewezen dat via internetfora een publiek debat met medeburgers de persoonlijke mening van burgers kan worden ontwikkeld en dat deze fora ook bijdragen tot beter burgerschap.

Het potentieel van het internet en daaraan gerelateerde netwerken en sociale mediaplatformen, hoewel thans nog onderbenut, voor de vormgeving van civiel en politiek burgerschap, vormt een uitdaging voor de ontwikkeling van een 'Glocal Cyber-Commons': een wereldwijd, virtueel platform, waarin lokale gemeenschappen en het openbaar en zinvol kunnen netwerken met het oog op de realisatie van voorzieningen die zowel lokaal als het mondiaal van belang zijn. Het lijkt er tevens op dat wereldwijd actieve ICT-bedrijven, die zo veel voordeel hebben gehaald uit het voldoen aan de persoonlijke en sociale behoeftes van consumenten, nu in staat zouden kunnen zijn om in dienst te staan van de verwezenlijking van actief burgerschap en de publieke zaak. Met dat gegeven in het achterhoofd 
heeft de groep die momenteel werkt aan de oprichting van een Wereldwijd Parlement van Burgemeesters een oproep heeft gedaan aan ICT-bedrijven om deel te nemen aan het ontwerpen van een virtueel platform voor het WPB. Een dergelijk platform zal zeker helpen om ten minste een aantal van de obstakels te omzeilen die het WPB-project in de weg kunnen staan.

Als de 21e eeuw zoals veelal wordt beweerd niet de 'eeuw van de staten' maar 'de eeuw van de steden' zal zijn, dan moet stedelijk bestuur ook gebruik maken van de technologie van die 21e eeuw. Dit kan de vorm aannemen van een 'Civic Facebook' waarin de 'vrienden' uit samenwerkende steden met elkaar overleggen; of van een Google Hangout-platform waarvan de deelnemers bestaan uit burgemeesters; of van een Cisco Systems cyberspace waarin niet alleen 'best practices' worden gedeeld, maar ook mondiaal overleg plaatsvindt tussen burgemeesters. In al die gevallen wordt informatietechnologie ingezet om in dienst te staan van de burgers, zoals oorspronkelijk de bedoeling was.

Er zullen vele obstakels uit de weg geruimd moeten worden, willen we middels een WPB op basis van stedelijke publieke belangen ook het wereldwijde publieke belang dienen. Praktische problemen van tijd, ruimte, geografie en financiën zouden een dergelijke ontwikkeling niet in de weg mogen staan. En met een 'Global Cyber-Commons' als de basis voor een Wereldwijd Parlement van Burgemeesters zullen deze mogelijke belemmeringen dat ook niet doen.

\section{De verklaring van de rechten van steden en stadbewoners}

Het spreken in termen van recht en rechten was en is cruciaal in het vaststellen van de legitimiteit van politieke gezag. In een wereld van onderlinge afhankelijkheid waarin steden hun gemeenschap niet alleen lokaal besturen, maar ook middels interstedelijke samenwerking het vermogen hebben ontwikkeld om sturing te geven aan mondiale ontwikkelingen en waarin de raakvlakken tussen stedelijke en wereldwijde publieke belangen steeds sterker worden, kan de formulering van recht en rechten op een krachtige wijze uitdrukking geven aan de opkomende wereldwijde bestuursfunctie van steden. Juist omdat het gezag en de legitimiteit van bestuur door steden is gevestigd - niet alleen in hun vermogen dit bestuur uit te voeren maar ook in hun aanspraak op bepaalde rechten - is een Wereldwijd Parlement van Burgemeesters een unieke vorm van interstedelijke samenwerking die een revolutie in de theorie en de praktijk van bestuur teweeg kan brengen, door het vestigen van een nieuwe vorm van politiek gezag gebaseerd op universele rechten.

De rechten van steden en stadsbewoners omvatten de onderstaande tien thema's:

1 Het recht van stadsbewoners op een transparant en verantwoordelijk bestuur. Zij hebben het recht betrokken te worden en te kunnen deelnemen aan de stedelijke publieke zaak. In andere woorden, het erkennen dat de rechten van de stad, de rechten van haar bewoners zijn en dat de bewoners recht hebben op directe participatie en representatie. 
2 Het recht op de uitoefening van alle bestuurlijke bevoegdheden, inclusief die tot het heffen van belastingen, over de volledige bevolking die is aangewezen op de stad en zijn voorzieningen (zij het middels transport, werkgelegenheid, cultuur, sport, ontspanning en andere sociale diensten), ongeacht of die personen binnen of buiten de formele grenzen van de stad wonen. In de praktijk betekent dit recht de rechtvaardige eis om de bevoegdheid te hebben de traditionele grenzen van de stad te verleggen zodat zij overeenkomen met het gehele stedelijke verzorgingsgebied. Dit impliceert het instellen van metropoolregio's.

3 Het recht op schone lucht, schoon water en op een omgeving met minimale (uiteindelijk geen) CO2-uitstoot, wat zich vertaalt in het recht om actie te ondernemen om een veilige en duurzame omgeving te scheppen, ongeacht de (in)activiteit van andere overheidslagen.

4 Het recht op een menswaardige verblijfsstatus, dat wil zeggen dat alle stedelingen, ongeacht hun immigratiestatus of de wijze waarop zij het land binnen zijn gekomen het recht hebben op een identiteitsbewijs dat toegang verschaft tot scholen, ziekenhuizen, transport en banen, onder de opschortende voorwaarde dat de houder zich houdt aan de wet.. In de praktijk is dit het recht op een 'stadsvisum' of een 'stedelijk identiteitsbewijs' dat, hoewel het op zich geen verblijfs- of burgerrechten op nationaal niveau waarborgt, in ieder geval een de facto lokale status kan normeren en in de loop der tijd wellicht een 'toegang tot staatsburgerschap' kan betekenen.

5 Het recht op fiscale en wettelijke autonomie van de stad passend bij haar verantwoordelijkheden en verplichtingen. Kort gesteld, het recht op een bepaalde mate van gedeelde soevereiniteit met andere, 'hogere' overheden (zoals provincies, kantons en nationale overheden) in de context van het nemen van beslissingen inzake stedelijke publieke belangen.

6 Het recht op een publieke ruimte, dat het essentiële karakter van de vrije, democratische stad als een gemeenschap van burgers codificeert. Het recht op de publieke ruimte is een voorwaarde voor vrije politieke en civiele participatie voor het individu en voor het maatschappelijke middenveld, en voor spel, kunst en zelfexpressie. Het is een belangrijke bron voor burgerlijke verbeeldingskracht, culturele creativiteit en egalitarisme.

7 Het recht op cultuur, te definiëren als het recht op creativiteit, verbeeldingskracht en spel als definiërende kenmerken van stedelijkheid en kosmopolitisme. Omdat cultuur synoniem is aan stedelijkheid kan het recht op cultuur gelijk worden gesteld aan de 'rechten van de stad'.

8 Het recht om actie te ondernemen en wetten vast te stellen wanneer 'hogere' overheden nalatig zijn in de gevallen waarin gevaar dreigt voor, of inbreuk wordt gemaakt op de rechten en belangen van stadsbewoners.

9 De bovenstaande rechten van steden en stadsbewoners kunnen en zullen niet prevaleren boven de rechten zoals die zijn geformuleerd door hogere overheden, soevereine natiestaten of internationale organen, of die van nietstedelingen. Deze rechten van steden en stadsbewoners zijn echter wel gelijkwaardig aan deze andere rechten. 
10 De specifieke rechten van de stad en stadsbewoners als hierboven genoemd sluiten onder geen beding het bestaan of de geldigheid van verdere, hierboven niet genoemde, rechten uit.

\section{Praktische voortgang naar een WPB}

Zoals ik eerder al stelde werd op vrijdag 19 september 2014 in het stadhuis van Amsterdam de derde planningssessie van het WPB gehouden. De bijeenkomst was georganiseerd door de burgemeesters van de Nederlandse G4-steden Amsterdam, Rotterdam, Utrecht en Den Haag. Dertig steden namen deel. Veel van hun burgemeesters waren persoonlijk aanwezig, zoals die van Athene, Bratislava, Waterloo (Canada), Wroclaw, Mannheim en Palermo, terwijl andere steden door hun locoburgemeesters of belangrijke plaatsvervangers vertegenwoordigd waren. Bovendien waren meer dan 50 stedelijke experts, leiders van stedelijke netwerken en wetenschappers aanwezig en namen deel aan de vier debatsessies die alles bijelkaar zes uur duurden. Deze unieke, uitdagende en productieve bijeenkomst werd bekroond door een formeel diner in de woning van de burgemeester.

Deze meest recent planningssessie bouwde voort op de voortgang die was bereikt in de hierboven genoemde eerdere planningssessies, waaronder een sessie in februari 2013 in Seoul, onder leiding van burgemeester Park Won Soon, en een volgende sessie in New York in oktober 2013, gehouden tijdens een Bloomberg Philanthropies CityLabbijeenkomst. Ons doel in deze derde sessie - de grootste en meest ambitieuze tot nog toe - was het bestuderen van de mogelijkheden om van theorie tot praktijk te komen, van het bespreken van de mogelijkheden en belemmeringen rondom het bijeenroepen van een Wereldwijd Parlement van Burgemeesters tot het overgaan op een daadwerkelijke proefbijeenkomst.

Volgend op de derde planningssessie, werd op maandag 22 september de eerste WPB Interdisciplinaire Workshop gehouden op de Campus Den Haag van de Universiteit Leiden. De workshop werd voorgezeten door burgemeester Van Aartsen van Den Haag en professor Jouke de Vries, decaan van de Campus Den Haag. Veertig experts op het gebied van bestuur, hergebruik van de ruimte ('placemaking') en digitale technologie verscherpten de resultaten van de sessie van de vrijdag ervoor, maar ook de technische en administratieve uitdagingen van een Wereldwijd Parlement van Burgemeesters. Het doel was om een blauwdruk te ontwikkelen voor de proefbijeenkomst van het Wereldwijd Parlement van Burgemeesters in Londen, die gehouden zal worden in september 2015.

Tijdens de interdisciplinaire workshop van maandag werd de rol van en de mogelijk te nemen acties door een WPB verfijnd, om zo de resultaten van de planningssessie van vrijdag verder uit te kunnen werken en tot een blauwdruk voor een WPB te kunnen komen. Een belangrijke stap die de burgemeesters en hun vertegenwoordigers hebben gezet is het komen tot een verklaring dat het WPB niet eenvoudigweg één van de vele stedelijke netwerken wordt, maar dat het zal gaan 
dienen als een bestuurslichaam dat politieke en machtgerelateerde kwesties aan zal pakken: het zal niet slechts een raadgevend samenwerkingsverband zijn maar een geïntegreerd 'sluitstuk' op reeds bestaande netwerken. Een sluitstuk dat zich bezig zal houden met alle relevante onderwerpen. Een sluitstuk dat steden van alle soorten en maten wil vertegenwoordigen en die zal streven naar de vorming van 'metropoolregio's' van het soort zoals onlangs in het leven geroepen door de Italiaanse minister-president Matteo Renzi: metropoolregio's die ook de voorsteden en het rurale ommeland omvatten.

Tevens werd benadrukt dat dit 'sluitstuk' steunt op de actieve deelname van de burgemeesters, omdat het WPB anders aan invloed zou inboeten. Het is daarom van groot belang dat zowel burgemeesters als kiezers direct voordeel zien in deelname van hun stad aan het WPB. Vanwege het belang van deelname door burgemeesters waren alle aanwezigen het erover eens dat een doeltreffend WPB een virtueel platform nodig heeft dat burgemeesters toestaat om samen te komen, overleg te plegen en tot beslissingen te komen via het internet, zonder de eigen kantoren te hoeven verlaten. Daartoe dient een nieuw en innovatief webplatform ontwikkeld te worden. Een platform dat interactie tussen de burgemeesters faciliteert, maakt het WPB tot een realistisch forum voor burgemeesters om hun lokale taken uit te voeren en tegelijkertijd samen te werken met burgemeesters van over de hele wereld. Samenwerking wordt daarmee een belangrijk element van de werking van het WPB. Ondanks de grote verschillen tussen burgemeesters wereldwijd maken de stad en de problemen die in alle steden leven burgemeesters veelal tot pragmatische probleemoplossers die voldoende gemeen hebben met elkaar om samen te kunnen werken, wat hun politieke achtergrond ook is. Deze kenmerkende eigenschap van burgemeesters waarborgt dat het WPB daadwerkelijk werk kan maken van de aanpak van mondiale problemen door de toepassing van innovatieve oplossingen te coördineren onder de deelnemende steden.

Wanneer burgemeesters in het WPB eenmaal een beslissing hebben genomen over een gezamenlijke aanpak van een mondiaal vraagstuk dan, zo was de opvatting van alle aanwezigen, zouden nationale staten en internationale organisaties moeten zorgen dat steden voldoende middelen en bevoegdheden krijgen om in staat te zijn op wereldniveau bestuur uit te oefenen. Steden zijn momenteel vaak belast met de verantwoordelijkheid voor problemen, zonder dat hen adequate middelen ter beschikking worden gesteld om ze op te lossen ('unfunded mandates'). Eén van de belangrijkste doelen voor een WPB is dan ook het ontwikkelen van een algemeen stedelijk platform voor het opeisen van de middelen en de autonomie die zij nodig hebben om hun lokale en mondiale taken uit te voeren. Deze eis dient gesteld te worden in termen van een 'stedelijk recht' op die middelen en die autonomie.

En tenslotte zou een WPB steden in staat stellen die stedelijke kwesties aan te pakken die zich wel lokaal manifesteren, maar waarvan de oorzaken zijn gelegen in omstandigheden waarop een stad zelf geen greep heeft. Een WPB kan gemeenschappelijke acties ondernemen om problemen als CO2-uitstoot, de aanwezigheid van immigranten zonder papieren in de stad en ongelijkheid aan te pakken. Ste- 
den kunnen het verschil maken door gemeenschappelijk beleid te voeren inzake onderwijs, stedelijke emissienormen, het invoeren van stadsvisa en door gezondheidszorg- en huisvestingsbeleid te voeren dat de armere lagen van de bevolking beschermt en mondiger maakt. Dergelijke acties impliceren geen 'wereldregering' volgens een model van beheersing en controle. Integendeel: in overeenstemming met het opkomende principe van 'soft governance', of informeel bestuur, is het WPB geconcipieerd als een 'bottom-up' orgaan gestoeld op informeel bestuur en consensus. Een dergelijk orgaan gaat te werk door invloed uit te oefenen op andere bestuurslagen en op de nonprofit- en particuliere sectoren door het voeren van verstandig beleid, het gebruiken van effectieve oplossingen en door gebruik te maken van het eenvoudige feit dat steden huisvesting bieden aan de meerderheid van de wereldbevolking en goed zijn voor bijna tachtig procent van het bruto mondiaal product.

Het Wereldwijde Parlement van Burgemeestersteam is momenteel bezig om een Mayoral Leadership Council (MLC) op te zetten. Deze raad bestaat uit burgemeesters wier steden betrokken zijn bij en zich inzetten voor de WPB-pilot en die willen helpen de koers uit te zetten van het experiment tot de pilot in 2015. De voorzitter van deze raad zal tegen het einde van dit jaar (2014) bekend worden gemaakt. De kandidaten voor de Adviesgroep van Experts, die zal bestaan uit sociale wetenschappers, technische leiders en vertegenwoordigers van de zakenwereld die zich inzetten voor duurzaamheid en stedelijk succes, zijn voorgedragen en de leden zullen begin 2015 benoemd worden. Zij zullen samen gaan werken met professor Barber, het WPB-team en de MLC. Het plan is nu om het proefparlement twee maal samen te laten komen. De bijeenkomsten staan voorlopig gepland voor 23 oktober 2015 in Londen, en voor 24 oktober 2015 in Bristol (de 'Groene Hoofdstad van Europa'). Kernthema van die bijeenkomsten is klimaatverandering en het doel is om invloed uit te kunnen oefenen op de Klimaatconferentie van de Verenigde Naties in Parijs (COP21) die gehouden zal worden in december 2015. Aan het project werken onder meer mee de gemeente Bristol (burgemeester George Ferguson), Harvey Goldsmiths Cities of Tomorrowinitiatief, de C-40 Climate Cities, en de congrescommissie van Nobelprijswinnaars voor klimaat, voorgezeten door $\mathrm{dr}$. John Schellnhuber.

Een Wereldwijd Parlement van Burgemeesters vormt het sluitstuk van een uitgebreid, wereldwijd netwerk van politieke en civiele samenwerking. Indien we economische én ecologische duurzaamheid willen realiseren en een leven willen lijden van vrede en rechtvaardigheid op een planeet waar alles en iedereen afhankelijk is van elkaar, dan moeten we het hoofd bieden aan de wrede wereld van ziekte zonder grenzen, oorlog zonder grenzen, markten zonder grenzen, misdaad zonder grenzen, technologie zonder grenzen en klimaatverandering zonder grenzen door zelf een nieuwe wereld van en voor burgers te maken: een wereld van democratie zonder grenzen, van burgers zonder grenzen en van hoop zonder grenzen. Samenwerkende steden kunnen de belofte van politieke en civiele wederzijdse afhankelijkheid waarmaken door deel te nemen aan het WPB. Zoals de polis ooit het centrum van de democratie en het respect was in de klassieke 
wereld kan de kosmopolis, vormgegeven middels een Wereldwijd Parlement van Burgemeesters, het centrum van de duurzaamheid en de rechtvaardigheid worden voor de moderne wereld.

Ga voor achtergrondnota's, informatie over de planningssessies, persberichten en videobeelden naar: www.globalparliamentofmayors.org 